\title{
RESEARCHES UNTO THE ADMINISTRATIVE METHOD OF ANTIBIOTICS FOR ACUTE BACILLARY DYSENTERY
}

\author{
TADASHI YUNOKI \\ Department of Pediatrics, School of Medicine, \\ Keio University \\ Yokohama Keiyukai Keiyu Hospital
}

(Received on November 24, 1958)

\section{PART 1. THE SMALL QUANTITY AND INTERMITTENT ADMINISTRATIVE METHOD OF CHLORAMPHENICOL FOR ACUTE BACILLARY DYSENTERY}

\section{Foreword}

Administration of antibiotics in short intervals (4 to 6 hours) in order to maintain an effective concentration in the blood has hitherto been a royal way of administrating antibiotics, and it is a well known fact that the method has yielded an excellent curative effect on various infectious diseases.

Price and Tompsett, however, obtained as good curative effect on pneumonia by administration of hydrophilic penicillin in intervals of 12 hours as in the continuous administration of previous authors. Ichihashi has also shown both clinically and experimentally intermittent administration of penicillin to be potent. Those and other authors forwarded clinical and experimental data, proving alternative nature of the need of maintenance of effective blood concentration.

Interested in those data in favor of new way of antibiotic administration, I am presently working on various diseases by intermittent administration of antibiotcs to compare the result with that by continuous administration.

Since 1952 I worked on 800 cases of acute bacillary dysentery by several antibiotics, evaluating various methods of administration.

2. An accurate periodical observation of curative effect of antibiotics

As an accurate periodical observation of curative effect of antibiotics, I pursued frequency of defecation and quality of stool in certain periods after administration of antibiotics, in order to see how soon and how long the effect of antibiotics will be manifest on bacillary dysentery.

The Table 1 gives an accurate observation of antidiarrheal and antipyretic time after administration of C. M. on typical patients. In the group of intermittent 
per oral administration of C.M., there comes, soon after ingestion of the medicine, a prolongation of frequency of defecation, which is evident in 3 to 12 hours with a highest incidence in about 7 hours.

Table 1

An Accurate Periodical Observation of Curative Effect After Administration of C.M. on Typical Patients

enen Frequency of defecation
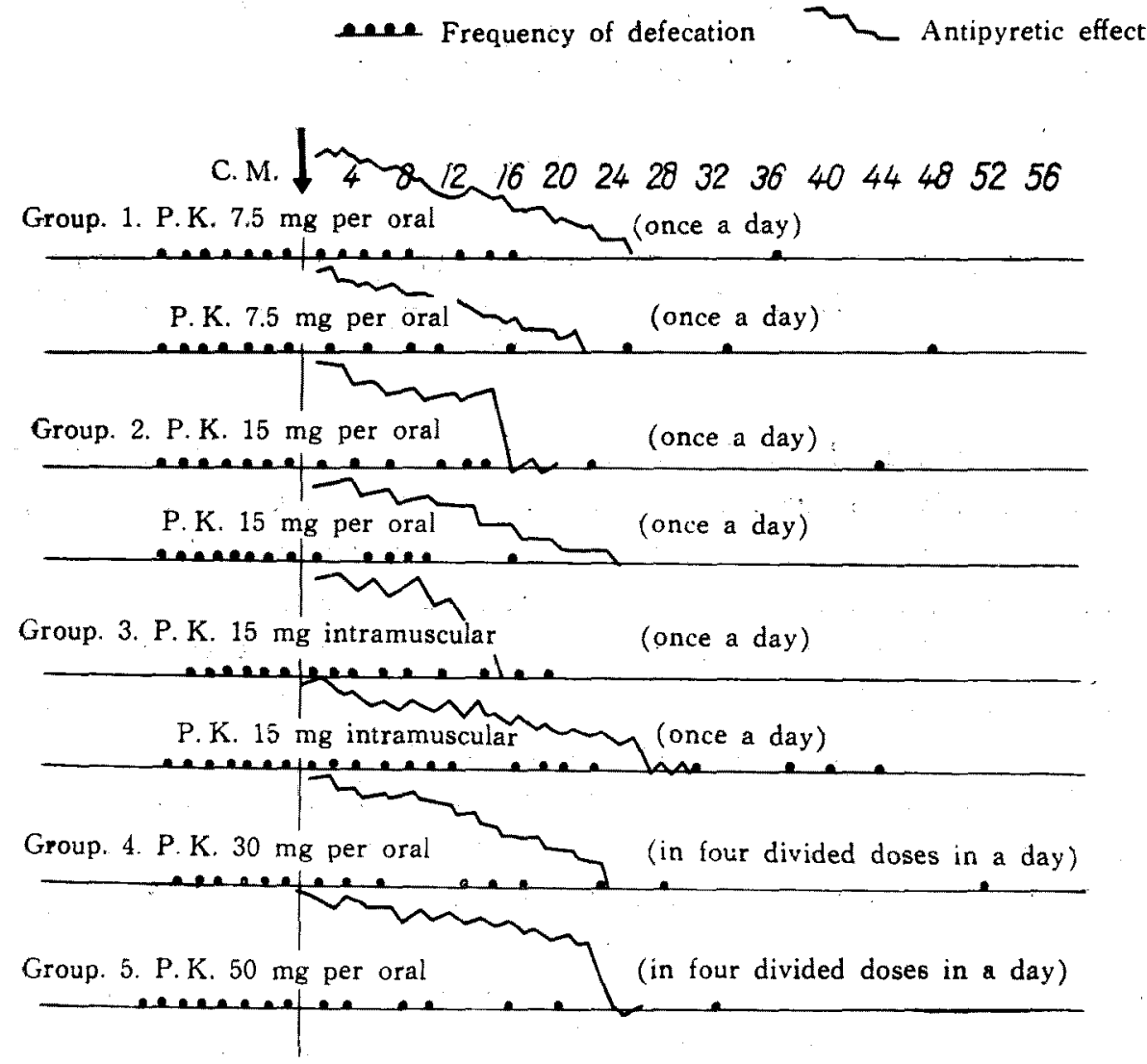

As for the comparison of curative effects in different doses and approaches of administration, group 1 (C. M. $7.5 \mathrm{mg}$ per kilo $\mathrm{gm}$ body weight per oral once a day) has less potent effect on the control of diarrhea than group 2 (C. M. $15 \mathrm{mg}$ per kilo gm body weight per oral once a day), while the latter does a better antidiarrheal work than group 3 (C. M. $15 \mathrm{mg}$ per kilo $\mathrm{gm}$ body weight intramuscular). In addition the group 2 obtained as good antidiarrheal and antipyretic effects as group 4 and 5 which were under the old method of continuous administration. Improvement of quality of stools after institution of the specific treatment is also as good (both macroscopically and microscopically).

These observations prove that regardless the way of administration a single 
does of C. M. gives rise to a pretty early and potent curative effect and maintains it for an unexpectedly long period.

3. Comparison of curative effects of intermittent administrative method

I scrutinized the intermittent administrative method of small dosis in three, items of 1) interval of administration, 2) dosis and 3) number of days of administration.

1) Comparison of curative effects of intermittent administrative method in different intervals of administration.

Table 2

\begin{tabular}{ccccc}
\hline $\begin{array}{c}\text { Intervals } \\
\text { of } \\
\text { administration }\end{array}$ & $\begin{array}{c}\text { Nnmbers } \\
\text { of } \\
\text { cases }\end{array}$ & $\begin{array}{c}\text { Ratio of } \\
\text { remarkable } \\
\text { effect } \\
\text { (n) }\end{array}$ & $\begin{array}{c}\text { Retio of extinction } \\
\text { of bacilli } \\
\text { within a week }\end{array}$ & $\begin{array}{c}\text { Relapse } \\
\text { and } \\
\text { exacerbation } \\
\%\end{array}$ \\
\hline Group A 12 hours interval & 20 & 72 & 60 & 10 \\
Group B 24 hours interval & 57 & 75 & 72 & 8 \\
Group C 48 hours interval & 57 & 62 & 57 & 11 \\
\hline
\end{tabular}

As in Table 2, among group A of 12 hours interval, group B of 24 hours interval and group C of 48 hours interval, the group B (namely group of one administration in a day) obtained a most stable result.

2) Comparison of curative effects of intermittent administrative methods in different doses.

Table 3

\begin{tabular}{|c|c|c|c|c|c|c|}
\hline \multicolumn{3}{|r|}{$\begin{array}{c}\text { Doses } \\
\text { of } \\
\text { administration }\end{array}$} & \multirow{2}{*}{$\frac{\begin{array}{c}\text { Numbers } \\
\text { of } \\
\text { cases }\end{array}}{15}$} & \multirow{2}{*}{$\begin{array}{c}\begin{array}{c}\text { Ratio of } \\
\text { remarkable } \\
\text { effect } \\
\%\end{array} \\
60\end{array}$} & \multirow{2}{*}{$\begin{array}{c}\begin{array}{c}\text { Ratio of extinction } \\
\text { of bacilli } \\
\text { within a week } \\
\%\end{array} \\
80\end{array}$} & \multirow{2}{*}{$\begin{array}{c}\begin{array}{c}\text { Relapse } \\
\text { and } \\
\text { exacerbation } \\
\%\end{array} \\
17\end{array}$} \\
\hline Group & A & $\begin{array}{c}\text { P.K. } 7.5 \mathrm{mg} \text { for } 3 \text { days } \\
24 \text { hour interval }\end{array}$ & & & & \\
\hline Group & B & $\begin{array}{l}\text { P. K. } 15 \mathrm{mg} \text { for } 3 \text { days } \\
24 \text { hout interval }\end{array}$ & 57 & 75 & 72 & 8 \\
\hline Group & $\mathrm{C}$ & $\begin{array}{l}\text { P. K. } 30 \mathrm{mg} \text { for } 3 \text { days } \\
24 \text { hour interval }\end{array}$ & 17 & 76 & 71 & 10 \\
\hline
\end{tabular}

As Table 3 shows, the group B gives a relatively best result among group A of C. M. $7.5 \mathrm{mg}$ per kilo gm body weight group B of C.M. $15 \mathrm{mg}$ per $\mathrm{kg} \mathrm{b}$. w. and group C of C. M. $30 \mathrm{mg}$ per kilo gm body weight. It seems that C. M. $15 \mathrm{mg}$ is sufficient; when less than $15 \mathrm{mg}$ is given there is poor curative result such as recurrence, while it is probably meaningless to increase dosis over $15 \mathrm{mg}$. Judging 
from my experiences it does not help much to use such a large dosis as over 50 $\mathrm{mg}$ per kilo gm in a day which was once a prevalent practice.

3) Comparison of curative effects of intermittent administrative method in different numbers of days of administration.

Table 4

\begin{tabular}{ccccc}
\hline $\begin{array}{c}\text { Number of days } \\
\text { of } \\
\text { administration }\end{array}$ & $\begin{array}{c}\text { Numbers } \\
\text { of } \\
\text { cases }\end{array}$ & $\begin{array}{c}\text { Ratio of } \\
\text { remarkable } \\
\text { effect } \\
\%\end{array}$ & $\begin{array}{c}\text { Ratio of extinction } \\
\text { of bacilli } \\
\text { within a week } \\
\%\end{array}$ & $\begin{array}{c}\text { Relapse } \\
\text { and } \\
\text { exacerbation } \\
\%\end{array}$ \\
\hline $\begin{array}{c}\text { P. K. } 15 \text { mg 3 times } \\
\text { A single day } \\
\text { P. K. } 15 \text { mg twic } \\
\text { Two days }\end{array}$ & 13 & 62 & 46 & 23 \\
$\begin{array}{c}\text { P. K. 15 mg } 3 \text { times } \\
\text { Three days }\end{array}$ & 24 & 71 & 62 & 17 \\
Five days & 57 & 75 & 72 & 8 \\
\hline
\end{tabular}

Among groups $\mathrm{A}$ of a single day, $\mathrm{B}$ of two days $\mathrm{C}$ of three days and $\mathrm{D}$ of five days, groups $\mathrm{C}$ and $\mathrm{D}$ have excellent results on control of bacteria and clinical pictures, and I feel strongly desirability of administratin over 3 days. This contradicts with the report of Hardy and a few others that the best is to give a large dosis in a short period of time.

4) Comparison of C.M. intermittent administrative method and continuous administrative method, when applied strictly on every other case.

Table 5

\begin{tabular}{ccccc}
\hline \hline $\begin{array}{c}\text { Administrative } \\
\text { method }\end{array}$ & $\begin{array}{c}\text { Number } \\
\text { of } \\
\text { cases }\end{array}$ & $\begin{array}{c}\text { Ratio of } \\
\text { remarkable } \\
\text { effect } \\
\%\end{array}$ & $\begin{array}{c}\text { Ratio of extinction } \\
\text { of bacilli } \\
\text { within a week } \\
\%\end{array}$ & $\begin{array}{c}\text { Relapse } \\
\text { and } \\
\text { exacerbation } \\
\%\end{array}$ \\
\hline $\begin{array}{c}\text { P. K. } 15 \mathrm{mg} \text { once a day } \\
\text { intermittent administration } \\
\text { for } 3 \text { days }\end{array}$ & 57 & 75 & 72 & 8 \\
$\begin{array}{c}\text { P. K. } 15 \text { mg once a day } \\
\text { intermittent administration } \\
\text { for } 5 \text { days }\end{array}$ & 48 & 75 & 80 & 8 \\
$\begin{array}{c}\text { P. K. 30 mg in 4 divided dosis } \\
\text { in a day continuous admin- } \\
\text { istration for } 3 \text { days }\end{array}$ & 30 & 73 & 60 & 10 \\
$\begin{array}{c}\text { P. K. 50 mg in 4 divided dosis } \\
\text { in a day continuous admin- } \\
\text { istration for 5 days }\end{array}$ & 16 & 81 & 81 & 6 \\
\hline
\end{tabular}

As I had, through previous data, a conviction that there will be sufficient 
effect with administration of C. M. $15 \mathrm{mg}$ per kilo $\mathrm{gm}$ body weight three times in 24 hours interval for three days, I went ahead to compare curative effect of this method with that of $30 \mathrm{mg}$ per kilo gm body weight in four divided doses in a day given for three days, applying them alternatively on every other case.

Between these two methods there was no difference at all in curative effects, as in shown with group 1 and 3 in Table 5 . About the same applies on groups 2 and 4 which were groups treated similarly for five days, I therefore, consider that my method of intermittent administration in small doses has as good curative effect as the old method of continuous administration, with only half amount of doses of the latter.

In conclusion Table 6 gives comparative curative effects in different methods of administration, which is an evidence of almost identical curative effects of administrative method of C.M. $15 \mathrm{mg}$ a day for 3 to 5 days with that of old method of continuous administration.

Table 6

Comparative Curative Effects in Differnt Methods of Administration.

\begin{tabular}{|c|c|c|c|c|c|c|}
\hline Name & $\begin{array}{l}\text { Intervals of } \\
\text { administra- } \\
\text { tion }\end{array}$ & $\begin{array}{l}\text { Administrative } \\
\text { method }\end{array}$ & $\begin{array}{c}\text { Numbers } \\
\text { of } \\
\text { cases }\end{array}$ & $\begin{array}{c}\begin{array}{c}\text { Ratio of } \\
\text { remarkable } \\
\text { effect } \\
\%\end{array} \\
\end{array}$ & $\begin{array}{c}\text { Ratio of } \\
\text { extinction } \\
\text { of bacilli } \\
\text { within } \\
\text { a week \% }\end{array}$ & $\begin{array}{c}\text { Relapse } \\
\text { and } \\
\text { exacerba } \\
\text { tion } \\
\%\end{array}$ \\
\hline \multirow{8}{*}{$\begin{array}{c}\text { A } \\
\text { Group }\end{array}$} & \multirow{2}{*}{ 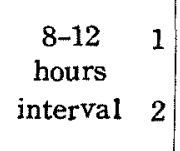 } & $\begin{array}{l}\text { C.M. P.K. } 15 \mathrm{mg} 3 \text { times } \\
\text { a single day }\end{array}$ & 13 & 62 & 46 & 23 \\
\hline & & $\begin{array}{l}\text { C.M. P.K. } 10 \mathrm{mg} 6 \text { times } \\
\text { twice a day for } 3 \text { days }\end{array}$ & 20 & 72 & 60 & 10 \\
\hline & \multirow{4}{*}{$\begin{array}{c}24 \\
\text { hours } \\
\text { interval }\end{array}$} & $\begin{array}{l}\text { C.M. P.K. } 7.5 \mathrm{mg} 3 \text { times } \\
\text { once a day for } 3 \text { days }\end{array}$ & 15 & 60 & 80 & 17 \\
\hline & & $\begin{array}{l}\text { C.M. P.K. } 15 \mathrm{mg} \text { twice } \\
\text { once a day for } 2 \text { days }\end{array}$ & 24 & 71 & 62 & 17 \\
\hline & & $\begin{array}{l}\text { C.M. P.K. } 15 \mathrm{mg} 3 \text { times } \\
\text { once a day for } 3 \text { days }\end{array}$ & 57 & 75 & 72 & 8 \\
\hline & & $\begin{array}{l}\text { C.M. P.K. } 15 \mathrm{mg} 5 \text { times } \\
\text { once a day for } 5 \text { days }\end{array}$ & 48 & 75 & 80 & 8 \\
\hline & \multirow{2}{*}{$\begin{array}{cc}48 & 7 \\
\text { hours } & \\
\text { interval } & 8\end{array}$} & $\begin{array}{l}\text { C.M. } 15-30 \mathrm{mg} \text { twice } \\
\text { once a } 2 \text { days for } 3 \text { days }\end{array}$ & 57 & 62 & 57 & 11 \\
\hline & & $\begin{array}{l}\text { C.M. P.K. } 30 \mathrm{mg} 3 \text { times } \\
\text { once a } 2 \text { days for } 5 \text { days }\end{array}$ & 21 & 75 & 80 & 10 \\
\hline B & \multirow{2}{*}{$\begin{array}{cc}6 & 9 \\
\text { hours } & \\
\text { interval } & \end{array}$} & $\begin{array}{l}\text { C.M. P.K. } 30 \mathrm{mg} 12 \text { times } \\
\text { in } 4 \text { divided dosis in a day } \\
\text { for } 3 \text { days }\end{array}$ & 30 & 73 & 60 & 10 \\
\hline Group & & $\begin{array}{l}\text { C.M. P.K. } 50 \mathrm{mg} 20 \text { times } \\
\text { in } 4 \text { divided dosis in a day } \\
\text { for } 5 \text { days }\end{array}$ & 16 & 81 & 81 & 6 \\
\hline
\end{tabular}

A Group: Discontinuous administratiue groups

B Group: Cotinuous administrative groups 
4. Conclusion

I have named my new method the small quantity and intermittent administrative method of Chloramphenicol for acute bacillary dysentery.

I performed sensitivity test on Shigellate bacilli recovered from patients in relapse who were given C.M. on previous attacks, using a standard strain of $\mathrm{E}_{W}$ 9 (Sh. Flex. 1b. 1674) with C. M. resistance of $0.78 \gamma / \mathrm{cc}$ and sensitivity of $1.56 \mathrm{\gamma} / \mathrm{cc}$. No bacilli were found highly resistant to C. M., as in shown in Table 7.

\section{Table 7}

Sensitivity Test on Shigellate Bacilli recovered from Patient in Relapse who were given C.M. on Previous Attacks. $(\gamma / \mathrm{cc})$

\begin{tabular}{|c|c|c|c|c|c|c|c|c|c|c|c|c|}
\hline \multirow{2}{*}{$\begin{array}{c}\text { Number } \\
\text { of } \\
\text { cases }\end{array}$} & \multirow{2}{*}{$\begin{array}{c}\text { Type } \\
\text { of } \\
\text { Shigellate } \\
\text { bacilli }\end{array}$} & \multirow[b]{2}{*}{ Name } & \multirow[b]{2}{*}{ Age } & \multirow[b]{2}{*}{ Sex } & \multirow{2}{*}{$\begin{array}{l}\text { Administ- } \\
\text { rative } \\
\text { method }\end{array}$} & \multicolumn{7}{|c|}{ Numbers of days after administration of C. M. } \\
\hline & & & & & & $\begin{array}{l}\text { Before } \\
\text { admin }\end{array}$ & 1 st & 2nd & $3 \mathbf{r d}$ & 4th & 5 th ${ }^{I}$ & ate of relapse \\
\hline 1 & F1. 2 a & & 2 & M & $4 \mathrm{Gr}$. & 1.56 & 1.56 & 1.56 & 1.56 & & 1.56 & (7th day) \\
\hline 2 & Fl. $2 \mathrm{a}$ & & 5 & M & 4 & 1.56 & 1.56 & 1.56 & & 0.78 & 1.56 & (10th day) \\
\hline 3 & F1. $2 \mathrm{~b}$ & & 7 & $\mathrm{~F}$ & 3 & 0.78 & 1.56 & 1.56 & 0.78 & & 0.78 & (6th day) \\
\hline 4 & F1. $2 \mathrm{~b}$ & & 4 & $\mathrm{M}$ & 3 & 3.13 & 3.13 & & & & 6.25 & (11th day) \\
\hline 5 & Sonnei & & 6 & $\mathrm{~F}$ & 1 & 0.78 & 1.56 & 0.78 & & & 1.56 & (9th day) \\
\hline 6 & Fl. $2 \mathrm{~b}$ & & 9 & $\mathrm{~F}$ & 1 & 3.13 & 3.13 & 3.13 & & 3.13 & 6.25 & (14th day) \\
\hline 7 & Fl. $2 \mathrm{~b}$ & & 7 & M & 1 & 3.13 & 3.13 & 1.56 & & & 3.13 & (7th day) \\
\hline 8. & Fl. $2 b$ & & 8 & M & 5 & 1.56 & 3.13 & & 1.56 & & 1.56 & (6th day) \\
\hline 9 & Fl. $2 \mathrm{a}$ & & 7 & $F$ & 6 & 1.56 & 1.56 & & 1.56 & & 3.13 & (10th day) \\
\hline 10 & FI. $1 \mathrm{~b}$ & & 4 & $F$ & 7 & 0.78 & 0.78 & & & & 0.78 & ( 6th day) \\
\hline 11 & Fl. $2 \mathrm{~b}$ & & 3 & $\mathrm{~F}$ & 8 & 6.25 & 6.25 & 6.25 & 6.25 & 6.25 & 6.25 & (14th day) \\
\hline 12 & Fl. $2 \mathrm{~b}$ & & 2 & $M$ & 2 & 0.78 & 0.78 & & & & 0.78 & ( 7th day) \\
\hline 13 & F1. $2 \mathrm{a}$ & & 5 & $\mathrm{~F}$ & 3 & 1.56 & 1.56 & 0.78 & & & 1.56 & (10th day) \\
\hline 14 & Sonnei & & 5 & M & 4 & 3.13 & 3.13 & & & & 3.13 & ( 6th day) \\
\hline 15 & F1. $2 \mathrm{~b}$ & & 4 & $\mathrm{~F}$ & 9 & 6.25 & 6.25 & 6.25 & 6.25 & 3.13 & 6.25 & (13th day) \\
\hline 16 & Fl. $2 \mathrm{~b}$ & & 4 & M & 9 & 1.56 & 1.56 & 1.56 & 1.56 & & 3.13 & (10th day) \\
\hline 17 & Fl. $2 \mathrm{a}$ & & 9 & $\mathrm{M}$ & 10 & 1.56 & 1.56 & 0.78 & & & 1.56 & ( 8th day) \\
\hline 18 & F1. $2 \mathrm{~b}$ & & 11 & $\mathrm{~F}$ & 10 & 0.78 & 1.56 & 1.56 & & & 1.56 & ( 7 th day) \\
\hline
\end{tabular}

PART 2. COMPARATIVE ON INTERMITTENT ADMINISTRATIVE METHODS OF VARIOUS ANTIBIOTICS FOR ACUTE BACILLARY DYSENTERY

\section{Foreword}

In the part 1 I scrutinized various administrative methods of C. M. on bacillary dysentery and found and intermittent administration of a small dose once a day to be as effective as the ordinary method of continuous administration.

From this conclusion I stepped forward on to comparative studies on effects 
and working mechanisms of small dose intermittent administration of various antibiotics. There are not too many reports on antibiotic administration in a long interval, one of such is by Nagaki and Takahashi, who publicized an administrative method of AC.M. $2 \mathrm{mg}$ per kilo gm intravenously once a day for five days and had some repercussions on various school of research. In U.S. A, on the other hand, Woodward and Smadel have practiced a long interval administrative method on typhoid fever.

Since 1954 I have made comparation studies on curative effects of various antibiotics.

2. A precise observation with special regard to the factor of time of curative effects of various antibiotic agents.

The table 8 gives a precise observation with special regard to the factor of time of curative effects of various antibiotic agents, that is, 1) time for antipyretic effect, 2) time for antidiarrheal effect, and B) time for bacteriostatic effect.

Table 8

An Accurate Periodical Qbservation of Carative Effect After Administration of Various Antibiotic on Typical Patients.

\begin{tabular}{|c|c|c|c|c|c|c|}
\hline Name & & $\begin{array}{l}\text { Administrative } \\
\text { method }\end{array}$ & $\begin{array}{c}\begin{array}{c}\text { Number } \\
\text { of } \\
\text { cases }\end{array} \\
\end{array}$ & $\begin{array}{l}\text { Time for } \\
\text { antipyretic } \\
\text { effect }\end{array}$ & $\begin{array}{c}\text { Time for } \\
\text { antidiarrheal } \\
\text { effect }\end{array}$ & $\begin{array}{c}\text { Time for } \\
\text { bacteriostatic } \\
\text { effect }\end{array}$ \\
\hline & 1 & $\begin{array}{l}\text { T. M. once a day } \\
\text { P. K. } 10 \mathrm{mg} \text { per oral }\end{array}$ & 12 & $11 \sim 19 \sim 24$ & $9 \sim 13 \sim 17$ & $12 \sim 24 \sim 48$ \\
\hline$\therefore$ & 2 & $\begin{array}{l}\text { C. M. once a day } \\
\text { P. K. } 15 \mathrm{mg} \text { per oral }\end{array}$ & 15 & $12 \sim 17 \sim 20$ & $7 \sim 9 \sim 12$ & $48 \sim 60 \sim 72$ \\
\hline A & 3 & $\begin{array}{l}\text { C. M. once a day } \\
\text { P. K. } 7.5 \mathrm{mg} \text { per oral }\end{array}$ & 7 & $12 \sim 24 \sim 48$ & $16 \sim 20 \sim 24$ & $48 \sim 72 \sim 96$ \\
\hline \multirow[t]{3}{*}{ Group } & 4 & $\begin{array}{l}\text { Ac. M. once a day } \\
\text { P. K. } 10 \mathrm{mg} \text { per oral }\end{array}$ & 11 & $12 \sim 21 \sim 26$ & $10 \sim 18 \sim 24$ & $18 \sim 26 \sim 48$ \\
\hline & 5 & $\begin{array}{l}\text { Ac. M. V. once a day } \\
\text { P. K. } 10 \mathrm{mg} \text { per oral }\end{array}$ & 12 & $11 \sim 20 \sim 23$ & $8 \sim 15 \sim 19$ & $11 \sim 24 \sim 48$ \\
\hline & 6 & $\begin{array}{l}\text { Ac. M. once a day } \\
\text { P. K. } 4 \mathrm{mg} \text { intramuscular }\end{array}$ & 18 & $7 \sim 18 \sim 19$ & $12 \sim 19 \sim 27$ & $22 \sim 36 \sim 72$ \\
\hline & 7 & $\begin{array}{l}\text { T. M. in four divided } \\
\text { doses in a day } \\
\text { P. K. } 10 \mathrm{mg} \text { per oral }\end{array}$ & 15 & $14 \sim 24 \sim 36$ & $18 \sim 24 \sim 28$ & $24 \sim 48 \sim 72$ \\
\hline $\begin{array}{c}\text { B } \\
\text { Group }\end{array}$ & 8 & $\begin{array}{l}\text { T. M. in four divided } \\
\text { doses in a day } \\
\text { P. K. } 30 \mathrm{mg} \text { per oral }\end{array}$ & 12 & $10 \sim 18 \sim 24$ & $11 \sim 17 \sim 20$ & $12 \sim 24 \sim 44$ \\
\hline " & 9 & $\begin{array}{l}\text { C. M. in four divided } \\
\text { doses in a day } \\
\text { P. K. } 30 \mathrm{mg} \text { per oral }\end{array}$ & 13 & $11 \sim 20 \sim 26$ & $8 \sim 10 \sim 16$ & $20 \sim 48 \sim 42$ \\
\hline
\end{tabular}

A. Discontinuous (intermittent) administrative method.

B. Continuous administrative method. 
TADASHI YUNOKI

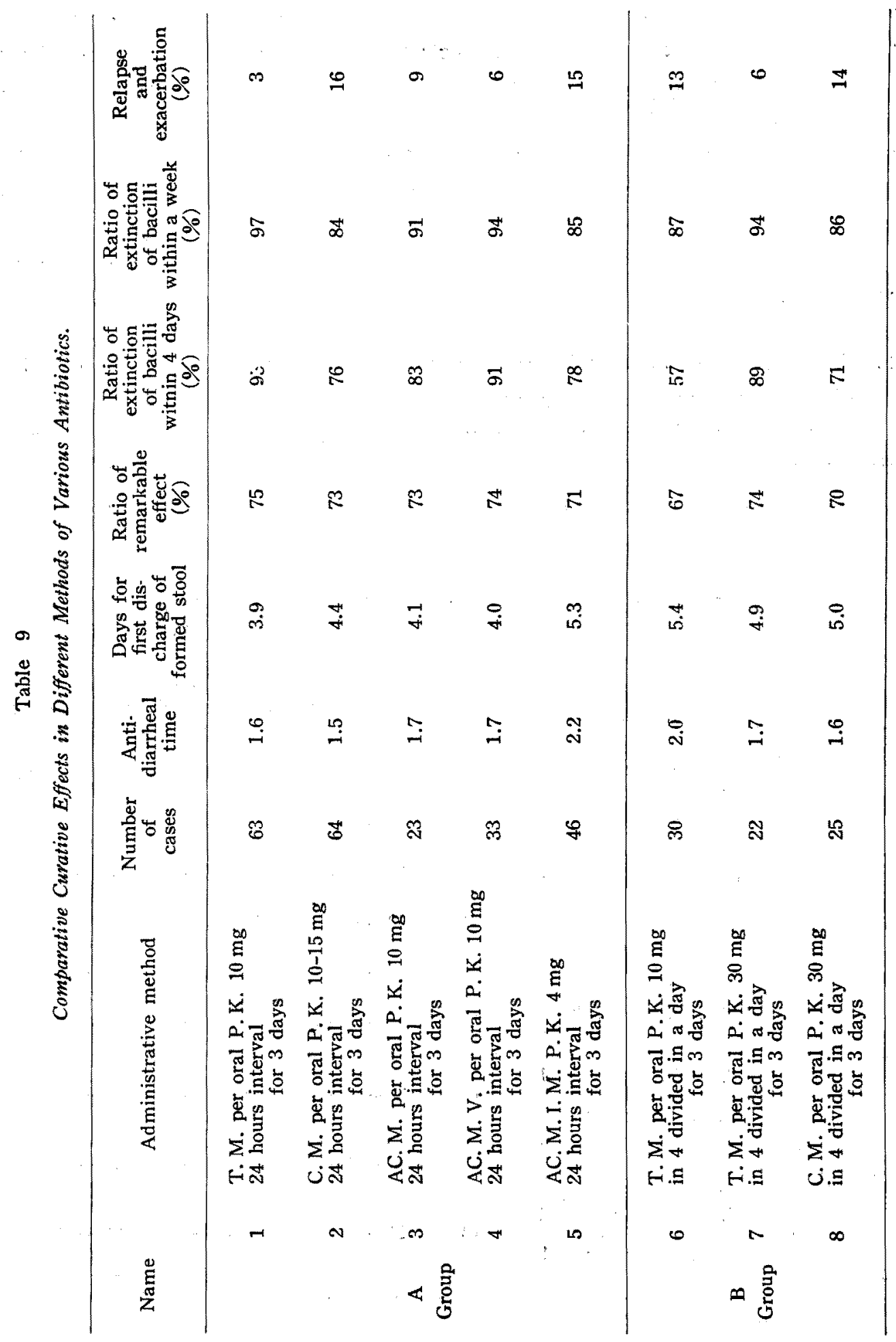


The table 9 illustrates comparatively the curative effects of various antibiotics, in which the groups 1 to 5 are by intermittent administrative method (once a day) and groups 6 to 8 are by ordinary cotinuous administrative methods (four times a day for three days).

In comparison of group 1 and 2 with T.M. and C.M. $10 \mathrm{mg}$ P.K. once a day for three days, C. M. had a quicker antidiarrheal effect, but was slower than T. M. in other respects (bacteriostatic effect and prevention of relapse).

When an intermittent administrative method and continuous administrative method both with same doses are compared (group 1 and 7) the group 7 showed much longer antidiarrheal time and was later in having formed stools; it showed less curative ratio with delayed bacterial extinction and higher incidence of relapse. The group 1, on the other hand, showed almost as good curative effects as group 8 , which employed an ordinary administrative method of T.M. $30 \mathrm{mg}$ P. K. a day in four divided doses for three days. In comparison of curative effects of T. M., AC. M. and C. M., T. M. was found best, AC. M. next, and C. M. to be inferior to the other two in the bactericidal effect.

When AC. M. per oral, AC. M. V. per oral and AC. M. I. M. (groups 3, 4 and 5) are compared, the per oral groups are superior to the intramuscular groups. Though such a result points to the great significance of the blood concentration of antibiotics, to which I will refer later, in the therapy of bacillary dysentery, there seems to be various other factors for explanation.

3. Consideration on the concentration in the blood and in the stool of various antibiotics

As the small dose intermittent administrative method is comparable clinically to the ordinary continuous administrative method, I performed a clinico-experimental study on the concentration after administration of antibiotics in both methods on cases of bacillary dysentery, making curves of the blood concentration, which was determined according to Torii-Kawakami dimentional diffusion method.

The table 10 shows the curves of intermittent administration of T. M. $10 \mathrm{mg}$ P. K. once a day and C.M. $15 \mathrm{mg} \mathrm{P.K.} \mathrm{once} \mathrm{a} \mathrm{day} \mathrm{in} \mathrm{contrast} \mathrm{to} \mathrm{cotinuous}$ administration of T. M. $30 \mathrm{mg}$ P. K. a day in four divided doses and C. M. $30 \mathrm{mg}$ P.K. a day in four divided doses. The groups under intermittent administrative method both of T.M. and C.M. yield a characteristic curve which reaches the maximal point with fast and - sharp crescendo in 2 to 6 hours and declines to infinitismal in 24 hours, while the ordinary continuous administrative method gives a characteristic curve in which the blood concentration increases gradually and maintains a certain level from 15 to 16 hours. To be added is the finding that 
C. M. has a remarkably higher blood concentration that T. M.

Table 10

Characteristic Curves on the Concentration in the Blood of Intermittent and Continuous Administrative Method of Various Antibiotics.

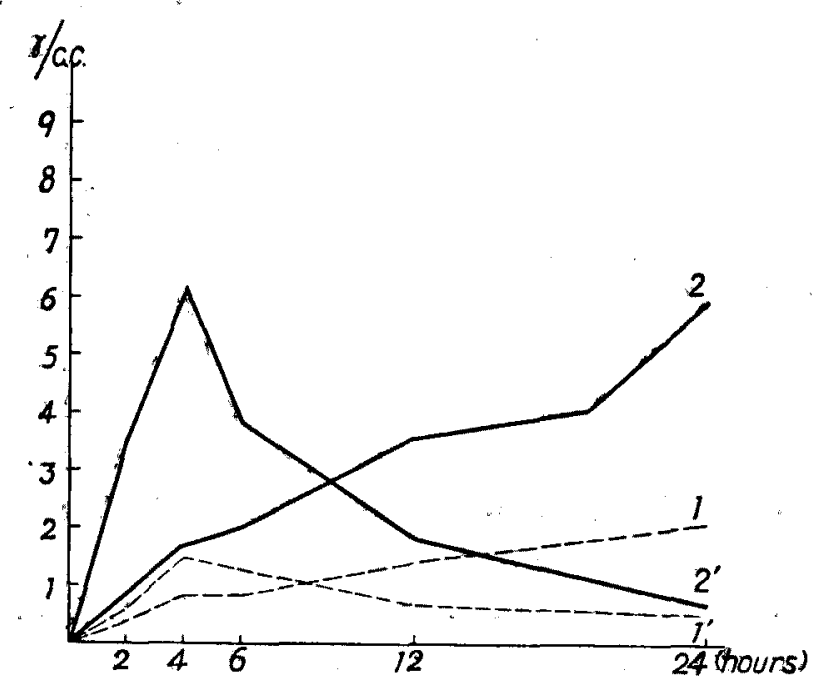

$1^{\prime}$ : T. M. P. K. $10 \mathrm{mg}$ once a day intermittent administration.

1 : T.M. P.K. $30 \mathrm{mg}$ in 4 divided dosis in a day continuous ad.

$2^{\prime}$ : C. M. P K. $10 \mathrm{mg}$ once a day intermittent administration.

2 : C. M. P. K. $30 \mathrm{mg}$ in 4 divided dosis in a continuous ad.

The table 11 is for comparison among a group under AC. M. $4 \mathrm{mg} \mathrm{P.} \mathrm{K.} \mathrm{I.} \mathrm{M.,}$ a group under AC. M. $10 \mathrm{mg}$ P. K. per oral, and a third group under AC. M. V. $10 \mathrm{mg}$ P. K. per oral, and shows that AC. M. V. reaches in relatively short time the maximal point of blood concentration which is one and half times that of $\mathrm{AC}$. M. and that the intramuscular groups reach the maximal point in the shortest time and declines relatively early.

The table 12 shows ratio of elimination in stool of various antibiotics: C. M. has an excellent rate of absorption through the gastrointestinal tract and has relatively low concentration in the stool, while T.M. and AC.M. have a lower rate of absorption through digestive canal and have a relatively higher concentration in the stool and S. M. has very poor rate of absorption but very high concentration in the stool.

When I secutinized the interrelationship of the curative effects, blood con: centration and concentration in the stool excepting the bacterocidal effect of the 
Table 11

Characteristic Curves on the Concentration in the Blood of the Same Family of Antibiotics.

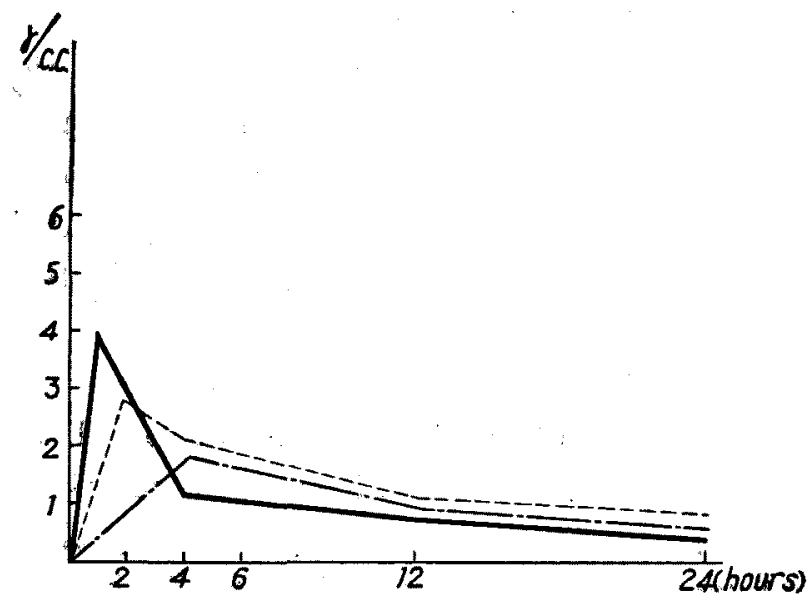

AC.M.P.K. $4 \mathrm{mg}$ I.M. once a day intermittent administration.

- - - AC.M.V. P.K. $10 \mathrm{mg}$ per oral once a day intermittent administration.

- - - AC. M. P. K. $10 \mathrm{mg}$ per oral once a day intermittent administration.

Table 12

Consideration on the Concentration in the Stool of Various Antibiotics.

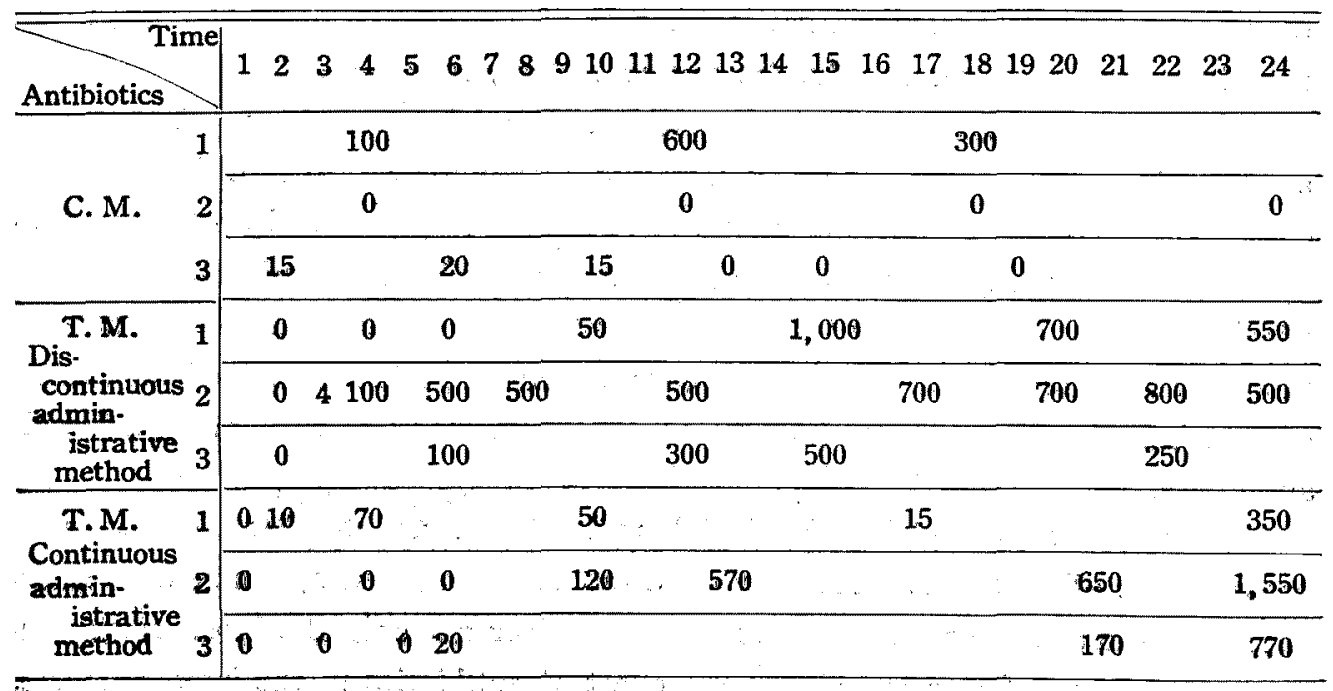

antibiotics, I forand the following facts. 
a) The importance of blood concentration of antibiotics is proven by the fact that per oral S. M. is less potent than T. M., AC. M. and C. M. due to its lower blood concentration and that AC. M. V. has better curative effect than AC. M. because of its higher blood concentration.

b) It seems that the high concentration in the stool of T. M. and AC. M., which is much higher than that of C. M., yields some favorable effect on the controle of Shigellate bacilli in the stool. Direct effect in the stool, however, seems to be secondary. S. M., for example, with the highest concentration only in the stool has a very poor effect on the control of the bacteria.

\section{Consideration and Conclusion}

I obtained following results through comparative study of various antibiotics by what I named in the Part 1 small dose intermittent administrative method.

1) The small dose intermittent administration of T. M., AC. M. and AC.M.V. showed by far the better curative effects than C. M. small dose intermittent administration, while combined intermittent administrations of T. M. and S. M. and C. M. and S.M. showed excellent results as are illustrated on a separate paper.

2) The small dose intermittent administration of T. M., AC. M., AC. M. V., and C. M. showed as good results as ordinary continuous per oral administration, reducing the amount of antibiotics needed to less than half of the amount with the ordinary method.

3) The intramuscular AC. M. small dose intermittent administration had essentially as good curative result as per oral AC. M. intermittent administration, though the former showed a little lower rate of bacteriostasis of the stool. It, therefore, seemed better to take the per oral route, if possible.

4) Among the groups of AC. M., AC. M. V. and intramuscular AC. M. which are all in the same family of antibiotics, the intramuscular AC. M. had poorest effect on the control of bocteria in the stool though it had the highest blood concentration. This implies an auxilliary effect of antibiotics discharged together within the stool, particularly of bacillary dysentery, for anihilation of the bacteria, though a high blood concentration of course is an important factor. The theory of Marshal, therefore, cannot be negated altogether today at least in regard with antibiotics.

5) In order to explain why T.M. and AC. M. are by far the better in bacteriocidal effect of the stool than C.M. (all of them given by small dose intermittent administrative method), we have to consider not only the blood concentration as a primary factor but also direct effect of antibiotics in the intestinal tract; ability of the individual for immune body production, etc., as combined and 
synergetic factors.

6) As for the small dose intermittent administration of T. M., AC. M., AC. M. V. and C. M., I reached a conclusion that

(a) 10-15 mg P.K. per oral as a preferable dose and

(b) interval of 24 hours (once a day) for more than 3 days, ideally for 5 days, as preferable interval and period of administration are better than ordinary continuous administration.

I, therefore, consider the small intermittent administrative method in lieu of ordinary methods as a safe and sure therapy.

7) In the antibiotic treatment of bacillary dysentery, we have to try to minimize recurrence, exacerbation, relapse of bacterial discharge in the stool and production of resistant bacteria, not to speak of improvement of clinical symptoms. This also has a great significance from epidemiological standpoint. As for the resistant strain of Shigellae there are investigations from various aspects to be performed in the future.

8) I like to add that I am presently undertaking an extremely interesting experiments both in vitro and in animals in order to ascertain the clitical data of my small dose intermittent administrative method. 